\title{
Rencontre avec Julian Curry
}

\section{(2) OpenEdition}

1 Journals

\section{Édition électronique}

URL : http://journals.openedition.org/shakespeare/1268

DOI : $10.4000 /$ shakespeare.1268

ISSN : 2271-6424

Éditeur

Société Française Shakespeare

\section{Édition imprimée}

Date de publication : 1 novembre 1993

Pagination : 197-208

Référence électronique

"Rencontre avec Julian Curry », Actes des congrès de la Société française Shakespeare [En ligne],

11 | 1993, mis en ligne le 01 janvier 2007, consulté le 19 avril 2019. URL : http://

journals.openedition.org/shakespeare/1268; DOI : 10.4000/shakespeare.1268

Ce document a été généré automatiquement le 19 avril 2019

(c) SFS 


\section{Rencontre avec Julian Curry}

